\title{
Eicosapentaenoic acid stimulates AMP-activated protein kinase and increases visfatin secretion in cultured murine adipocytes
}

\author{
Silvia LORENTE-CEBRIÁN*, Matilde BUSTOS†, Amelia MARTI*, \\ J. Alfredo MARTINEZ* and Maria J. MORENO-ALIAGA* \\ *Department of Nutrition, Food Science, Physiology and Toxicology, University of Navarra, 31008 Pamplona, Spain, and \\ †Division of Hepatology and Gene Therapy, Center for Applied Medical Research (CIMA), University of Navarra, \\ 31008 Pamplona, Spain
}



\begin{abstract}
Visfatin is an adipokine highly expressed in visceral AT (adipose tissue) of humans and rodents, the production of which seems to be dysregulated in excessive fat accumulation and conditions of insulin resistance. EPA (eicosapentaenoic acid), an n-3 PUFA (polyunsaturated fatty acid), has been demonstrated to exert beneficial effects in obesity and insulin resistance conditions, which have been further linked to its reported ability to modulate adipokine production by adipocytes. TNF- $\alpha$ (tumour necrosis factor- $\alpha$ ) is a pro-inflammatory cytokine whose production is increased in obesity and is involved in the development of insulin resistance. Control of adipokine production by some insulin-sensitizing compounds has been associated with the stimulation of AMPK (AMPactivated protein kinase). The aim of the present study was to examine in vitro the effects of EPA on visfatin production and the potential involvement of AMPK both in the absence or presence of TNF- $\alpha$. Treatment with the pro-inflammatory cytokine TNF- $\alpha(\mathrm{l} \mathrm{ng} / \mathrm{ml})$ did not modify visfatin gene expression and protein secretion in primary cultured rat adipocytes. However, treatment of these primary adipocytes with EPA $(200 \mu \mathrm{mol} / \mathrm{l})$ for $24 \mathrm{~h}$ significantly increased visfatin secretion $(P<0.001)$ and mRNA gene expression $(P<0.05)$. Moreover, the stimulatory effect of EPA on visfatin secretion was prevented by treatment with the AMPK inhibitor Compound $C$, but not with the PI3K (phosphoinositide 3-kinase) inhibitor LY294002. Similar results were observed in 3T3-LI adipocytes. Moreover, EPA strongly stimulated AMPK phosphorylation alone or in combination with TNF- $\alpha$ in 3T3-LI adipocytes and pre-adipocytes. The results of the present study suggest that the stimulatory action of EPA on visfatin production involves AMPK activation in adipocytes.
\end{abstract}

\section{INTRODUCTION}

Visfatin/Nampt/PBEF (pre-B-cell colony-enhancing factor) is a newly discovered adipokine, which is mainly produced by visceral AT (adipose tissue) in both humans and rodents [1]. Conflicting results have been found regarding the role played by visfatin in obesity and insulin resistance. In fact, some studies have shown that visfatin production is enhanced during obesity and Type 2 diabetes development [1,2], whereas others have found that plasma visfatin is reduced in obesity [3,4] and insulin resistance [5], and suggest that visfatin might not be related to insulin sensitivity in humans [6-8].

Key words: adipose tissue, AMP-activated protein kinase (AMPK), eicosapentaenoic acid (EPA), tumour necrosis factor- $\alpha$ (TNF- $\alpha$ ), visfatin.

Abbreviations: AICAR, 5-amino-4-imidazolecarboxamide-1- $\beta$-D-ribofuranoside; AMPK, AMP-activated protein kinase; AT, adipose tissue; DMEM, Dulbecco's modified Eagle's medium; DTT, dithiothreitol; EPA, eicosapentaenoic acid; FBS, foetal bovine serum; IL-6, interleukin-6; NEFA, non-esterified fatty acid; PI3K, phosphoinositide 3-kinase; PKB, protein kinase B; PUFA, polyunsaturated fatty acid; TNF- $\alpha$, tumour necrosis factor- $\alpha$.

Correspondence: Dr Maria J. Moreno-Aliaga (email mjmoreno@unav.es). 
A further conflicting point concerning the action of visfatin is its potential role as an insulin mimetic which was initially shown by Fukuhara et al. [1]. In fact, these authors observed that visfatin significantly increased glucose uptake and triacylglycerol (triglyceride) storage in 3T3-L1 adipocytes and L6 myocytes, as well as decreased glucose production from hepatocytes. Moreover, in vivo administration of visfatin to KKAy rodents (obese and insulin-resistant) decreased circulating levels of glucose and insulin and, thus, improved insulin sensitivity, which was also observed in streptozotocintreated mice [1]. However, other investigators have not observed any insulin-mimetic effects of visfatin in adipogenesis, glucose uptake, insulin signalling in adipocytes or glucose-lowering effects [9], and the original article [1] has been retracted [10].

Little is known about the regulation of visfatin production by adipocytes. It has been shown that glucose stimulates visfatin release in adipocytes. This stimulatory effect of glucose on visfatin secretion involves the PI3K (phosphoinositide 3-kinase) and PKB (protein kinase B; also known as Akt) pathways [11]. Moreover, visfatin gene expression is up-regulated by glucocorticoids and down-regulated by lipolytic agents (forskolin, isoprenaline and cholera toxin) in 3T3-L1 adipocytes $[12,13]$. However, the role played by TNF- $\alpha$ (tumour necrosis factor- $\alpha$ ) and IL-6 (interleukin-6), as well as other pro-inflammatory cytokines in visfatin production, is still controversial. Indeed, although some studies have observed that TNF- $\alpha$ and IL-6 inhibit visfatin synthesis in 3T3-L1 adipocytes [12,14] and in vivo [15], an assay performed in human adipocytes has shown that treatment with $\mathrm{TNF}-\alpha$ induces an up-regulation in visfatin production [16]. In order to better elucidate the actions of TNF- $\alpha$ on this adipokine, in the present study we analyse its short-term $(24 \mathrm{~h})$ and long-term $(96 \mathrm{~h})$ effects on both visfatin secretion and gene expression in a model of primary cultured rat adipocytes anchored to a collagen matrix, which simulates basement membrane attachment, producing a more physiological environment [17].

A regulatory role for dietary fats, such as palmitate, a saturated NEFA (non-esterified fatty acid; 'free fatty acid') and oleate (a mono-unsaturated NEFA) on visfatin gene expression has also been described in 3T3-L1 murine adipocytes [18].

EPA (eicosapentaenoic acid) is a dietary PUFA (polyunsaturated fatty acid) from the omega-3 family $(n-3$ PUFA). EPA has been reported to exert beneficial effects on health, including improvements of inflammatory conditions, obesity, insulin resistance and Type 2 diabetes [19-22]. Some of these actions have been related to the anti-inflammatory properties of $n-3$ PUFAs $[19,23]$ and to their ability to modulate adipokine production, such as adiponectin and leptin, both in vivo $[19,20]$ and in vitro $[17,24]$. In this context, a recent study by our group has suggested that the insulin-sensitizing effects of in vivo
EPA treatment in cafeteria-fed animals could also be related to a stimulatory action on visfatin gene expression in visceral fat [21]; however, the direct effects of EPA on visfatin production have not yet been studied.

Several studies have reported the regulatory role of AMPK (AMP-activated protein kinase) activation on adipokine production, such as adiponectin [25]. In addition, the antidiabetic efficacy of some insulin sensitizers, such as metformin and glitazones, involves the activation of AMPK [26]. Some studies have suggested that AMPK activation could be involved in EPA-induced improvements in insulin sensitivity [27]. However, controversial results have also been reported suggesting that dietary fish oils do not activate AMPK in mouse tissues [28]. To our knowledge, there are no studies addressing the ability of EPA to modulate AMPK activation in adipocytes.

In the present study, we examined the direct effects of EPA on visfatin gene expression and protein secretion in both primary rat and 3T3-L1 adipocytes. Additionally, we also investigated whether EPA activates AMPK in 3T3-L1 adipocytes and the potential involvement of this kinase on the action of EPA on visfatin.

\section{MATERIAL AND METHODS}

\section{Animals}

Male Wistar rats were obtained from the Applied Pharmacobiology Center (CIFA-Pamplona, Spain). The animals were housed in cages in temperature-controlled rooms $\left(22 \pm 2^{\circ} \mathrm{C}\right)$ with a light/dark cycle $(12 \mathrm{~h} / 12 \mathrm{~h})$. All experimental procedures were performed according to National and Institutional Guidelines for Animal Care and Use, with the approval of the Ethical Committee for Animal Care and Use at the University of Navarra.

\section{Adipocyte isolation and primary culture}

Adipocytes were isolated from epididymal fat depots of Wistar rats, as previously described [24]. Briefly, AT fragments were digested with type I collagenase at $37^{\circ} \mathrm{C}$ with gentle shaking for $30 \mathrm{~min}$. The resulting cell suspension was diluted in Hepes buffer $(5 \mathrm{mmol} / \mathrm{l} \mathrm{D}$-glucose, $2 \% \mathrm{BSA}, 135 \mathrm{mmol} / \mathrm{l} \mathrm{NaCl}, 2.2 \mathrm{mmol} / 1 \mathrm{CaCl}_{2} \cdot 3 \mathrm{H}_{2} \mathrm{O}$, $1.25 \mathrm{mmol} / \mathrm{l} \quad \mathrm{MgSO}_{4} \cdot 7 \mathrm{H}_{2} \mathrm{O}, 0.45 \mathrm{mmol} / \mathrm{l} \quad \mathrm{KH}_{2} \mathrm{PO}_{4}$, $2.17 \mathrm{mmol} / \mathrm{l} \mathrm{Na} \mathrm{HPO}_{4}$ and $10 \mathrm{mmol} / \mathrm{l}$ Hepes, $\mathrm{pH} 7.4$ ) and then filtered through a $400 \mu \mathrm{m}$ nylon mesh. The isolated adipocytes were washed three times and resuspended in low-glucose (5 mmol/l) DMEM (Dulbecco's modified Eagle's medium) supplemented with $1 \%(\mathrm{v} / \mathrm{v}) \mathrm{FBS}$ (foetal bovine serum) and incubated for $30-40 \mathrm{~min}$ at $37^{\circ} \mathrm{C}$.

The isolated adipocytes were plated on $500 \mu \mathrm{l}$ of a collagen matrix (Purecol; Inamed Biomaterials) in six-well culture plates and, after $50 \mathrm{~min}$ incubation, culture medium containing the different treatments was added and cells were cultured for 24 or $96 \mathrm{~h}$. 


\section{Cell culture and differentiation of 3T3-LI cells}

Mouse 3T3-L1 cells were purchased from American Type Culture Collection and differentiated as described previously [29]. Briefly, at 2 days post-confluence pre-adipocytes were cultured for $48 \mathrm{~h}$ in DMEM containing $25 \mathrm{mmol} / \mathrm{l}$ glucose, $10 \%(\mathrm{v} / \mathrm{v})$ FBS, antibiotics and supplemented with dexamethasone $(1 \mu \mathrm{mol} / \mathrm{l})$, isobutylmethylxanthine $(0.5 \mathrm{mmol} / \mathrm{l})$ and insulin $(10 \mu \mathrm{g} /$ $\mathrm{ml})$. Then, cells were cultured with $10 \%(\mathrm{v} / \mathrm{v}) \mathrm{FBS}$ and $10 \mu \mathrm{g} / \mathrm{ml}$ insulin in DMEM for $48 \mathrm{~h}$. Cells were then cultured without insulin until day 6-7 post-confluence when cells were completely differentiated to adipocytes. Prior to the addition of the appropriate treatments, cells were serum-starved overnight and then treated.

\section{Treatments}

EPA (Cayman Chemical) was dissolved in ethanol, TNF- $\alpha$ (Phoenix Peptide) was dissolved in water, and AICAR (5-amino-4-imidazolecarboxamide-1- $\beta$-D-ribofuranoside; Sigma), LY294002 (Sigma) and Compound C (Calbiochem) were dissolved in DMSO. All compounds were prepared as $1000 \times$ stock solutions and were then added to the culture medium. Control cells were treated with the same amount of the corresponding vehicle (ethanol and/or DMSO). EPA (100 and $200 \mu \mathrm{mol} / \mathrm{l}$ ) and/or TNF- $\alpha(1 \mathrm{ng} / \mathrm{ml})$ and/or the AMPK stimulator AICAR $(2 \mathrm{mmol} / \mathrm{l})$ were added to the medium at the same time; however, when the selective PI3K inhibitor LY294002 $(50 \mu \mathrm{mol} / \mathrm{l})$ and AMPK inhibitor Compound C $(20 \mu \mathrm{mol} / \mathrm{l})$ were used, adipocytes were pre-incubated for $30 \mathrm{~min}$ with the inhibitors prior to the addition of EPA $(200 \mu \mathrm{mol} / \mathrm{l})$.

\section{Assays}

The total amount of visfatin secreted into culture medium was determined through the use of an ELISA kit for $\mathrm{rat} /$ mouse visfatin (Alpco Diagnostics).

\section{Analyses of mRNA}

Total RNA was extracted using TRIzol ${ }^{\circledR}$ according to the manufacturer's protocol (Invitrogen). Following this, the RNA was incubated with an RNAse-free DNase kit (Ambion). RNA $(1 \mu \mathrm{g})$ was reverse-transcribed to cDNA using MMLV (Moloney-murine-leukaemia virus) reverse transcriptase (Invitrogen). Visfatin mRNA and $18 \mathrm{~S}$ levels were determined by quantitative real-time PCR using the ABI PRISM 7000HT Sequence Detection System (Applied Biosystems). Quantitative real-time PCR analysis was performed as previously described [24]. Fold changes of gene expression were calculated using the $2^{-\Delta \Delta \mathrm{Ct}}$ method.

\section{Western blot analysis}

3T3-L1 adipocytes were cultured and induced to differentiate as previously described [29]. AMPK activation was determined both in mature adipocytes (7 days post-differentiation) and in pre-confluent (20-30\%) preadipocytes. Cells were serum-starved overnight $(18 \mathrm{~h})$ and then incubated with the appropriate treatment.

Cells $\left(0.5 \times 10^{6}\right)$ were washed in PBS, lysed in $200 \mu \mathrm{l}$ of double-strength SDS sample buffer containing DTT (dithiothreitol) $[60 \%$ glycerol, $150 \mathrm{mmol} / \mathrm{l}$ Tris/ $\mathrm{HCl}$ (pH 6.8), 2 mmol/l DTT, $2 \%$ (w/v) SDS and $0.005 \%$ Bromophenol Blue] and heat-denatured before resolution on SDS/PAGE ( $7.5 \%$ gels). Protein immunoblotting was performed as previously described [30]. Briefly, proteins were transferred on to nitrocellulose membranes (BioRad Laboratories) and then stained with Ponceau Red solution to verify equal loading of proteins. Membranes were then blocked for $2 \mathrm{~h}$ at room temperature $\left(22^{\circ} \mathrm{C}\right)$ in TBST [50 mmol/l Tris/HCl (pH 7.6), $200 \mathrm{mmol} / \mathrm{l} \mathrm{NaCl}$ and $0.1 \%$ Tween 20] with $2 \%(\mathrm{w} / \mathrm{v})$ BSA (fraction V; Sigma) containing $10 \%(\mathrm{w} / \mathrm{v})$ non-fat dried skimmed milk, washed twice and then incubated overnight with an anti-(phospho-AMPK $\alpha$ ) $\left(\mathrm{Thr}^{172}\right)$ antibody (Cell Signaling Technology) diluted 1:1000. After further washings, membranes were incubated with horseradish peroxidaseconjugated $\operatorname{IgG}$ fraction of goat anti-rabbit IgG (Cell Signaling Technology) diluted 1:5000 in TBST for $1 \mathrm{~h}$. Phospho-AMPK $\alpha\left(\mathrm{Thh}^{172}\right)$ was visualized on Amersham Hyperfilm (GE Healthcare) using the CL+Chemiluminescence kit (GE Healthcare). For reprobing of the Western blots, antibodies were stripped from membranes using stripping buffer $[62.5 \mathrm{mmol} / \mathrm{l}$ Tris/ $\mathrm{HCl}(\mathrm{pH} 6.8)$, $2 \%(\mathrm{w} / \mathrm{v})$ SDS and $100 \mathrm{mmol} / \mathrm{l} 2$-mercaptoethanol] for 30 min at $50^{\circ} \mathrm{C}$, washing the membranes with TBST and, after making sure that the original signal was removed, we reprobed with AMPK $\alpha$ (Cell Signaling Technology) diluted 1:1000 and incubated overnight. Then, the bands were visualized as described above.

\section{Data analysis}

Results are means \pm S.E.M. The statistical analysis was performed by repeated measures one-way ANOVA, followed by a Dunnet's post-hoc test, or by a two-way ANOVA. Differences were considered as statistically significant at $P<0.05$. The statistical analyses were performed using GraphPad Prism software (GraphPad Software).

\section{RESULTS}

\section{Effects of EPA on visfatin secretion in primary cultured rat adipocytes}

Incubation of primary rat adipocytes with EPA at $200 \mu \mathrm{mol} / \mathrm{l}$ induced an increase in basal visfatin secretion as compared with control cells both at $24 \mathrm{~h}(169.7 \pm$ $18.0 \%$ of control, $P<0.001)$ and $96 \mathrm{~h}(122.5 \pm 10.8 \%$ of control, $P<0.05)$ of treatment (Figure 1A). This stimulatory effect of EPA on visfatin seems to be dose-dependent, since no significant changes in visfatin release were observed when adipocytes were incubated with lower doses of EPA (results not shown). 
A)

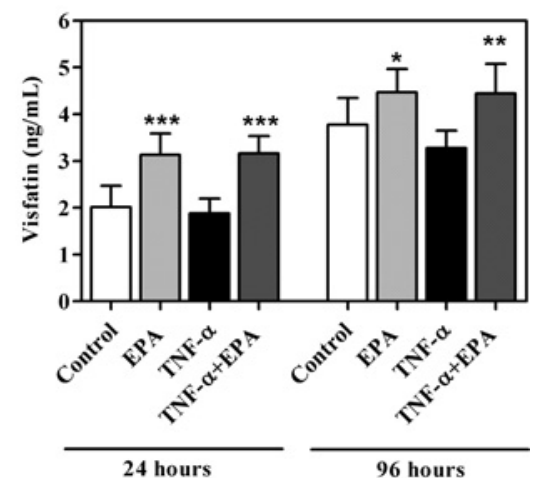

B)

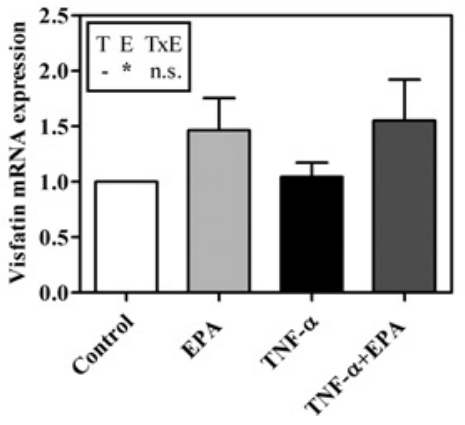

Figure I Effects of EPA and TNF- $\alpha$ on visfatin secretion and mRNA levels

(A) Effects of EPA $(200 \mu \mathrm{mol} / \mathrm{l})$ and TNF- $\alpha(\mathrm{I} \mathrm{ng} / \mathrm{ml})$ on visfatin secretion in isolated primary cultured rat adipocytes over 24 and $96 \mathrm{~h}$ of treatment. ${ }^{*} P<0.05,{ }^{* *} P<0.01$ and ${ }^{* * *} P<0.001$ as compared with control. (B) Visfatin mRNA gene expression levels after $24 \mathrm{~h}$ of EPA treatment with and without TNF- $\alpha$. Gene expression data were analysed by two-way ANOVA $(* P<0.05)$. Results are representative of at least five independent experiments. T, TNF- $\alpha$; E, EPA; TXE, interaction between TNF- $\alpha$ and EPA treatments.

Taking into account that some studies have described that TNF- $\alpha$ alters visfatin production in adipocytes, we tested the effects of the pro-inflammatory cytokine in our model of primary cultured rat adipocytes and their potential ability to reverse the stimulatory actions of EPA on visfatin. However, in the model of cultured adipocytes used in the present study, the presence of the pro-inflammatory cytokine TNF- $\alpha(1 \mathrm{ng} / \mathrm{ml})$ did not modify visfatin secretion after short-term $(24 \mathrm{~h})$ or long-term $(96 \mathrm{~h})$ treatment. Interestingly, the stimulatory effect of $200 \mu \mathrm{mol} / \mathrm{l} \mathrm{EPA}$ on visfatin secretion was also observed in the presence of TNF- $\alpha$ in the medium.

The expression pattern of the visfatin gene after $24 \mathrm{~h}$ of treatment was similar to that observed for visfatin secretion. Thus incubation of adipocytes with EPA alone or in combination with TNF- $\alpha$ significantly increased visfatin mRNA gene expression levels (Figure 1B).

\section{Effects of AICAR, Compound C and LY294002 on EPA-stimulated visfatin production in primary cultured rat adipocytes and murine 3T3-LI adipocytes} Using the same model of primary cultured rat adipocytes, we observed that treatment with the AMPK inhibitor Compound C $(20 \mu \mathrm{mol} / \mathrm{l})$ abolished the stimulatory action of EPA on visfatin release. We also determined the effects of EPA $(200 \mu \mathrm{mol} / \mathrm{l})$ in combination with the AMPK stimulator AICAR (2 mmol/l). Interestingly, cotreatment of EPA+AICAR further stimulated visfatin production $(163.8 \pm 20.1 \%$ of control for EPA, $P<0.01$ and $185.1 \pm 23.3 \%$ of control for EPA+AICAR-treated cells, $P<0.01$ ), suggesting a certain additive effect of both agents. However, the PI3K inhibitor LY294002 (50 $\mu \mathrm{mol} / \mathrm{l})$ did not significantly modify the stimulatory effect induced by EPA on visfatin secretion (Figure 2A).

In order to verify the role of AMPK in the stimulatory action of EPA on visfatin, we also tested the ability of Compound $\mathrm{C}$ to reverse EPA actions on visfatin in 3T3L1 adipocytes. In agreement with the results observed in primary adipocytes, incubation of mature 3T3-L1 adipocytes with EPA $(200 \mu \mathrm{mol} / \mathrm{l})$ induced a strong increase in visfatin secretion after treatment for $24 \mathrm{~h}(130.2 \pm 13.4 \%$ of control, $P<0.05)$. Interestingly, this effect was significantly prevented $(P<0.01)$ by the addition of the AMPK inhibitor Compound C (Figure 2B), but not with the PI3K inhibitor LY294002 (results not shown), as previously observed in primary cultured rat adipocytes. The pattern of the effects of EPA on visfatin gene expression was similar to the results obtained for visfatin secretion in 3T3-L1 adipocytes. Thus visfatin mRNA levels were significantly $(P<0.05)$ enhanced after 24 h of treatment with $200 \mu \mathrm{mol} / 1 \mathrm{EPA}$, whereas the presence of Compound $\mathrm{C}$ prevented the stimulatory effect of EPA on visfatin gene expression (Figure 2C). These findings suggest a potential involvement of AMPK on EPAstimulated visfatin production in murine adipocytes.

\section{Effects of EPA on AMPK activation in 3T3-LI adipocytes}

In order to assess whether EPA directly stimulates AMPK activation, 3T3-L1 adipocytes and pre-adipocytes were treated with EPA $(100 \mu \mathrm{mol} / \mathrm{l}$ and $200 \mu \mathrm{mol} / \mathrm{l})$.

Incubation of both 3T3-L1 mature adipocytes (Figure 3A) and pre-adipocytes (Figure 3B) with EPA resulted in a positive activation of AMPK in a dosedependent manner. In contrast, the pro-inflammatory cytokine TNF- $\alpha(1 \mathrm{ng} / \mathrm{ml})$ did not phosphorylate AMPK $\left(\mathrm{Thr}^{172}\right)$ in $3 \mathrm{~T} 3-\mathrm{L} 1$ adipocytes. Interestingly, the presence of EPA (100 and $200 \mu \mathrm{mol} / \mathrm{l})$ in TNF- $\alpha$-treated adipocytes also stimulated AMPK phosphorylation to similar levels to that which was observed in adipocytes treated with EPA alone. As expected, AICAR ( $2 \mathrm{mmol} / \mathrm{l})$ induced a strong increase in AMPK activation, whereas 
A)

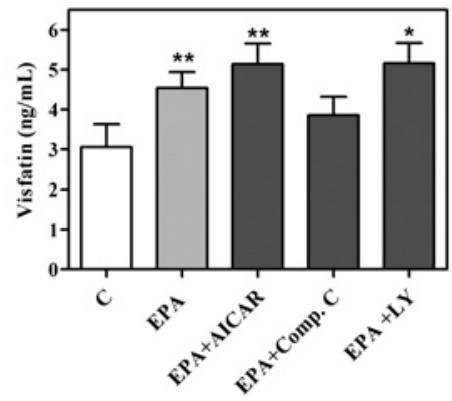

B)



C)

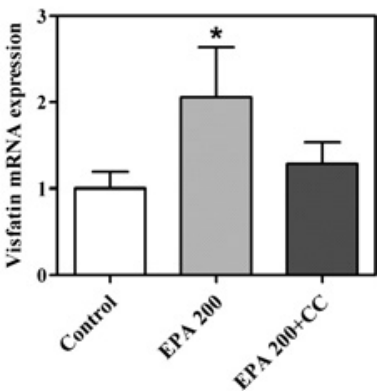

Figure 2 Role of AMPK and PI3K/PKB signalling pathways on EPA-stimulated visfatin secretion and mRNA levels

(A) Effects of EPA $(200 \mu \mathrm{mol} / \mathrm{l})$ on visfatin secretion alone or in the presence of AICAR $(2 \mathrm{mmol} / \mathrm{l})$, Compound C (20 $\mu \mathrm{mol} / \mathrm{l})$ or LY294002 $(50 \mu \mathrm{mol} / \mathrm{l})$ after $24 \mathrm{~h}$ of treatment in primary cultured rat adipocytes. Effects of EPA $(200 \mu \mathrm{mol} / \mathrm{l})$ on visfatin secretion $(B)$ and mRNA gene expression $(C)$ in the absence or presence of Compound $C(20 \mu \mathrm{mol} / \mathrm{l})$ in $3 \mathrm{~T} 3$-LI adipocytes. ${ }^{*} P<0.05$ and ${ }^{* *} P<0.01$ as compared with control cells; ${ }^{b} P<0.01$ as compared with EPA-treated cells. Results are representative of four to six independent experiments.

A) 3T3-L1 adipocytes (7 days post-differentiation).



B) 3T3-L1 pre-adipocytes.

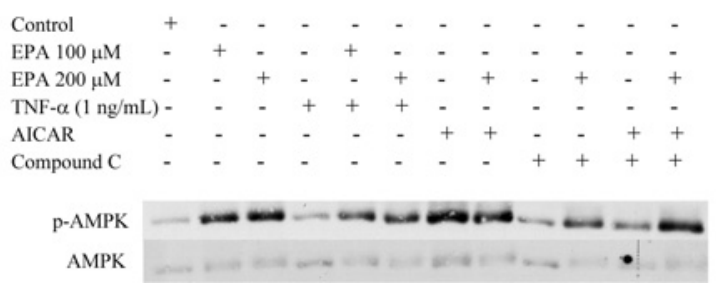

Figure 3 Effects of EPA on AMPK activation with or without TNF- $\alpha$, AICAR and Compound C

Analysis of AMPK activation in 3T3-LI adipocytes (A) and pre-adipocytes (B) 30 min after treatment with EPA (100 and $200 \mu \mathrm{mol} / \mathrm{l})$ in the presence and absence of TNF- $\alpha(\mathrm{Ig} / \mathrm{ml})$, AICAR $(2 \mathrm{mmol} / \mathrm{l})$ and Compound C (20 $\mu \mathrm{mol} / \mathrm{l})$. Whole-cell lysates were subjected to gel electrophoresis and immunoblotted using specific antibodies for phospho-AMPK $\alpha\left(\mathrm{Thr}^{172}\right.$ ) and AMPK $\alpha$ as described in the Material and methods section. The blots shown are representative of three independent experiments showing the effects of different treatments on AMPK phosphorylation. p-AMPK, phospho-AMPK.

the co-treatment with Compound C $(20 \mu \mathrm{mol} / \mathrm{l})$ was able to partially block the AMPK phosphorylation induced by both EPA and AICAR.

All of these results clearly demonstrate the ability of EPA to activate AMPK phosphorylation ( $\mathrm{Thr}^{172}$ ) in 3T3-L1 cells (both adipocytes and pre-adipocytes).

\section{DISCUSSION}

Several studies have reported the ability of $n-3$ PUFAs to improve insulin sensitivity by controlling adipokine production [22]. In fact, EPA regulates leptin and adiponectin production in vitro $[17,24]$ and in vivo $[19,27,31]$.

A recent study by our group also demonstrated the ability of EPA ethyl ester administration to prevent the decrease in visfatin gene expression observed in highfat-diet-induced obese rats [21]. An inverse relationship with HOMA (homoeostasis model assessment), an index of insulin resistance, was also found, suggesting that the insulin-sensitizing effects of EPA could be related to its stimulatory action on visfatin gene expression in visceral fat [21]. In the present study, the finding that a direct stimulatory effect of EPA on both visfatin gene expression and protein secretion in primary adipocytes is relevant. Thus it suggests that the up-regulation of visfatin gene suggested in visceral AT observed in our previous study after in vivo EPA administration was not only due to the reducing effects of EPA treatment on the size of this fat depot, but also by a direct transcriptional up-regulation of the visfatin gene by this $n-3$ PUFA.

Other studies have reported the ability of dietary fatty acids to modulate visfatin gene expression. In contrast with the $n-3$ PUFA EPA, the saturated NEFA palmitate and mono-unstaturated NEFA oleate down-regulated visfatin mRNA gene expression in 3T3-L1 adipocytes and pre-adipocytes [18]. Moreover, this down-regulation of visfatin was suggested as a potential mechanism to directly induce insulin resistance by oleate and palmitate in vitro [18]. In this context, it has also been shown that a synthetic mixture including stearate, oleate, linoleate, linolenate and arachidonate normalized the increase in visfatin release induced by treatment with the insulinsensitizing PPAR- $\gamma$ (peroxisome-proliferator-activated receptor $\gamma$ ) agonist rosiglitazone in human isolated adipocytes [32]. These findings suggest a differential 
regulation of visfatin depending of the type of dietary fat and support our hypothesis that visfatin up-regulation by EPA could be another mechanism by which $n-3$ PUFAs may improve insulin sensitivity.

We have tested whether incubation with $1 \mathrm{ng} / \mathrm{ml}$ TNF$\alpha$, a dose known to induce lipolysis and inflammatory markers in our model of cultured adipocytes (results not shown), was able to reverse the EPA-stimulated visfatin secretion. Our results have revealed that TNF- $\alpha$ did not induce any significant change in visfatin secretion, both in the presence or absence of EPA after 24 and $96 \mathrm{~h}$ of treatment. This fact suggests that, in our culture conditions, the stimulatory action of EPA on visfatin seems not to be related to the ability of $n-3$ PUFAs to block the inflammatory pathway [19]. The available data in the literature concerning the regulation of visfatin by pro-inflammatory cytokines are controversial. Indeed, some studies have observed that TNF- $\alpha$ and IL- 6 induced a time- and dose-dependent down-regulation of visfatin gene expression levels in 3T3-L1 adipocytes $[12,14]$. However, an assay performed in human adipocytes has shown that visfatin mRNA levels were highly increased after $24-72 \mathrm{~h}$ of incubation with TNF- $\alpha$ [16]. The disparity observed may be related to differences in the type (primary compared with cell lines) and source (rat, mouse or human) of cultured adipocytes, the concentration of TNF- $\alpha$ used and the duration of the treatment.

AMPK is a protein kinase that regulates important metabolic processes, whose activation induces multiple effects on liver, AT and muscle metabolism [33]. AMPK activation has been associated with the regulation of adipokine production, such as adiponectin [25]. Recently, long-chain fatty acyl analogues, which are AMPK activators, have been proposed as potential agents for treating Type 2 diabetes [34]. Thus some studies have suggested that AMPK activation could be involved in EPA-induced improvements in insulin sensitivity [27], although there was no data showing evidence of a direct activation of AMPK by EPA in adipocytes. Our present study clearly demonstrated that treatment of adipocytes with EPA strongly stimulated AMPK activation. These results are in accordance with previously published studies which reported that PUFAs induced activation of this signal transduction protein in liver [35]. Moreover, a recent study also demonstrated an increase in intestinal glucose absorption potentially via acute activation of AMPK after $n-3$ PUFA feeding during gestation in pigs [36]. However, other investigators did not find any changes in AMPK phosphorylation in mouse tissues (liver, skeletal muscle and heart) after feeding a diet supplemented with fish oil [28].

An interesting finding of the present study was that the stimulatory effect of EPA on visfatin secretion in adipocytes involved the AMPK-activation pathway, but not PI3K. In support of the present study, recent work performed in myocytes has also demonstrated that cells exposed to AICAR or glucose restriction, which also increase AMPK activity, had increased Nampt/visfatin mRNA expression and protein levels, indicating that AMPK regulates Nampt expression induced by glucose restriction in these insulin-target cells [37].

EPA has been shown to stimulate the PI3K pathway in hepatoma cells [38] and adipocytes (results not shown). Moreover, glucose-stimulated visfatin secretion involves the PI3K/PKB pathway [11]. However, the fact that PI3K inhibitor treatment did not modify EPA-stimulated visfatin release either in primary rat or 3T3-L1 adipocytes suggests that the PI3K signalling pathway is not likely to be involved in the stimulatory effect of EPA on visfatin secretion.

In summary, our results show for the first time that EPA increases visfatin expression and secretion in primary adipocytes, and that AMPK activation is intimately involved in the EPA-stimulatory action in visfatin production. These mechanisms could account for the insulin-sensitizing actions of EPA.

\section{FUNDING}

This work was supported by the Spanish Ministry of Education and Culture [grant number AGL200604716/ALI] and 'Línea Especial de Investigación: Nutrición, Salud y Obesidad' from the University of Navarra. S.L.-C. is supported by a doctoral grant FPU 'Formación de Profesorado Universitario' from the Spanish Ministry of Education and Culture.

\section{REFERENCES}

1 Fukuhara, A., Matsuda, M., Nishizawa, M., Segawa, K., Tanaka, M., Kishimoto, K., Matsuki, Y., Murakami, M., Ichisaka, T., Murakami, H. et al. (2005) Visfatin: a protein secreted by visceral fat that mimics the effects of insulin. Science 307, 426-430

2 Filippatos, T. D., Derdemezis, C. S., Kiortsis, D. N., Tselepis, A. D. and Elisaf, M. S. (2007) Increased plasma levels of visfatin/pre-B cell colony-enhancing factor in obese and overweight patients with metabolic syndrome. J. Endocrinol. Invest. 30, 323-326

3 Wang, P., van Greevenbroek, M. M., Bouwman, F. G., Brouwers, M. C., van der Kallen, C. J., Smit, E., Keijer, J. and Mariman, E. C. (2007) The circulating PBEF/NAMPT/visfatin level is associated with a beneficial blood lipid profile. Pflugers Arch. 454, 971-976

4 Sun, G., Bishop, J., Khalili, S., Vasdev, S., Gill, V., Pace, D., Fitzpatrick, D., Randell, E., Xie, Y. G. and Zhang, H. (2007) Serum visfatin concentrations are positively correlated with serum triacylglycerols and down-regulated by overfeeding in healthy young men. Am. J. Clin. Nutr. 85, 399-404

5 Li, L., Yang, G., Li, Q., Tang, Y., Yang, M., Yang, H. and $\mathrm{Li}, \mathrm{K}$. (2006) Changes and relations of circulating visfatin, apelin, and resistin levels in normal, impaired glucose tolerance, and type 2 diabetic subjects. Exp. Clin. Endocrinol. Diabetes 114, 544-548

6 Pagano, C., Pilon, C., Olivieri, M., Mason, P., Fabris, R., Serra, R., Milan, G., Rossato, M., Federspil, G. and Vettor, R. (2006) Reduced plasma visfatin/pre-B cell colony-enhancing factor in obesity is not related to insulin resistance in humans. J. Clin. Endocrinol. Metab. 91, 3165-3170 
7 Varma, V., Yao-Borengasser, A., Rasouli, N., Bodles, A. M., Phanavanh, B., Lee, M. J., Starks, T., Kern, L. M., Spencer, III, H. J., McGehee, Jr, R. E. et al. (2007) Human visfatin expression: relationship to insulin sensitivity, intramyocellular lipids, and inflammation. J. Clin. Endocrinol. Metab. 92, 666-672

8 Dogru, T., Sonmez, A., Tasci, I., Bozoglu, E., Yilmaz, M. I., Genc, H., Erdem, G., Gok, M., Bingol, N., Kilic, S. et al. (2007) Plasma visfatin levels in patients with newly diagnosed and untreated type 2 diabetes mellitus and impaired glucose tolerance. Diabetes Res. Clin. Pract. 76, 24-29

9 Revollo, J. R., Korner, A., Mills, K. F., Satoh, A., Wang, T., Garten, A., Dasgupta, B., Sasaki, Y., Wolberger, C., Townsend, R. R. et al. (2007) Nampt/PBEF/visfatin regulates insulin secretion in $\beta$-cells as a systemic NAD biosynthetic enzyme. Cell Metab. 6, 363-375

10 Fukuhara, A., Matsuda, M., Nishizawa, M., Segawa, K., Tanaka, M., Kishimoto, K., Matsuki, Y., Murakami, M., Ichisaka, T., Murakami, H. et al. (2007) Retraction. Science 318, 565

11 Haider, D. G., Schaller, G., Kapiotis, S., Maier, C., Luger, A. and Wolzt, M. (2006) The release of the adipocytokine visfatin is regulated by glucose and insulin. Diabetologia 49, 1909-1914

12 Kralisch, S., Klein, J., Lossner, U., Bluher, M., Paschke, R., Stumvoll, M. and Fasshauer, M. (2005) Hormonal regulation of the novel adipocytokine visfatin in 3T3-L1 adipocytes. J. Endocrinol. 185, R1-R8

13 Sommer, G., Garten, A., Petzold, S., Beck-Sickinger, A. G., Bluher, M., Stumvoll, M. and Fasshauer, M. (2008) Visfatin/PBEF/Nampt: structure, regulation and potential function of a novel adipokine. Clin. Sci. 115, 13-23

14 Kralisch, S., Klein, J., Lossner, U., Bluher, M., Paschke, R., Stumvoll, M. and Fasshauer, M. (2005) Interleukin-6 is a negative regulator of visfatin gene expression in 3T3-L1 adipocytes. Am. J. Physiol. Endocrinol. Metab. 289, E586-E590

15 Li, L., Yang, G., Shi, S., Yang, M., Liu, H. and Boden, G. (2009) The adipose triglyceride lipase, adiponectin and visfatin are downregulated by tumor necrosis factor- $\alpha$ $(\mathrm{TNF}-\alpha$ ) in vivo. Cytokine 45, 12-19

16 Hector, J., Schwarzloh, B., Goehring, J., Strate, T. G., Hess, U. F., Deuretzbacher, G., Hansen-Algenstaedt, N., Beil, F. U. and Algenstaedt, P. (2007) TNF- $\alpha$ alters visfatin and adiponectin levels in human fat. Horm. Metab. Res. 39, 250-255

17 Perez-Matute, P., Marti, A., Martinez, J. A., Fernandez-Otero, M. P., Stanhope, K. L., Havel, P. J. and Moreno-Aliaga, M. J. (2005) Eicosapentaenoic fatty acid increases leptin secretion from primary cultured rat adipocytes: role of glucose metabolism. Am. J. Physiol. Regul. Integr. Comp. Physiol. 288, R1682-R1688

18 Wen, Y., Wang, H. W., Wu, J., Lu, H. L., Hu, X. F. and Cianflone, K. (2006) Effects of fatty acid regulation on visfatin gene expression in adipocytes. Chin. Med. J. 119, 1701-1708

19 Perez-Matute, P., Perez-Echarri, N., Martinez, J. A., Marti, A. and Moreno-Aliaga, M. J. (2007) Eicosapentaenoic acid actions on adiposity and insulin resistance in control and high-fat-fed rats: role of apoptosis, adiponectin and tumour necrosis factor- $\alpha$. Br. J. Nutr. 97, 389-398

20 Rossi, A. S., Lombardo, Y. B., Lacorte, J. M., Chicco, A. G., Rouault, C., Slama, G. and Rizkalla, S. W. (2005) Dietary fish oil positively regulates plasma leptin and adiponectin levels in sucrose-fed, insulin-resistant rats. Am. J. Physiol. Regul. Integr. Comp. Physiol. 289, R486-R494

21 Perez-Echarri, N., Perez-Matute, P., Marcos-Gomez, B., Martinez, J. A. and Moreno-Aliaga, M. J. (2008) Effects of eicosapentaenoic acid ethyl ester on visfatin and apelin in lean and overweight (cafeteria diet-fed) rats. Br. J. Nutr. 28, 1-9

22 Flachs, P., Rossmeisl, M., Bryhn, M. and Kopecky, J. (2009) Cellular and molecular effects of $n-3$ polyunsaturated fatty acids on adipose tissue biology and metabolism. Clin. Sci. 116, 1-16
23 Perez-Echarri, N., Perez-Matute, P., Marcos-Gomez, B., Baena, M. J., Marti, A., Martinez, J. A. and

Moreno-Aliaga, M. J. (2008) Differential inflammatory status in rats susceptible or resistant to diet-induced obesity: effects of EPA ethyl ester treatment. Eur. J. Nutr. $47,380-386$

24 Lorente-Cebrian, S., Perez-Matute, P., Martinez, J. A., Marti, A. and Moreno-Aliaga, M. J. (2006) Effects of eicosapentaenoic acid (EPA) on adiponectin gene expression and secretion in primary cultured rat adipocytes. J. Physiol. Biochem. 62, 61-69

25 Lihn, A. S., Jessen, N., Pedersen, S. B., Lund, S. and Richelsen, B. (2004) AICAR stimulates adiponectin and inhibits cytokines in adipose tissue. Biochem. Biophys. Res. Commun. 316, 853-858

26 Fryer, L. G., Parbu-Patel, A. and Carling, D. (2002) The anti-diabetic drugs rosiglitazone and metformin stimulate AMP-activated protein kinase through distinct signaling pathways. J. Biol. Chem. 277, 25226-25232

27 Flachs, P., Mohamed-Ali, V., Horakova, O., Rossmeisl, M., Hosseinzadeh-Attar, M. J., Hensler, M., Ruzickova, J. and Kopecky, J. (2006) Polyunsaturated fatty acids of marine origin induce adiponectin in mice fed a high-fat diet. Diabetologia 49, 394-397

28 Dobrzyn, A., Dobrzyn, P., Miyazaki, M. and Ntambi, J. M. (2005) Polyunsaturated fatty acids do not activate AMP-activated protein kinase in mouse tissues. Biochem. Biophys. Res. Commun. 332, 892-896

29 Moreno-Aliaga, M. J. and Matsumura, F. (2002) Effects of 1,1,1-trichloro-2,2-bis( $p$-chlorophenyl)-ethane $\left(p, p^{\prime}-\mathrm{DDT}\right)$ on 3T3-L1 and 3T3-F442A adipocyte differentiation. Biochem. Pharmacol. 63, 997-1007

30 Bustos, M., Beraza, N., Lasarte, J. J., Baixeras, E., Alzuguren, P., Bordet, T. and Prieto, J. (2003) Protection against liver damage by cardiotrophin-1: a hepatocyte survival factor up-regulated in the regenerating liver in rats. Gastroenterology 125, 192-201

31 Neschen, S., Morino, K., Rossbacher, J. C., Pongratz, R. L., Cline, G. W., Sono, S., Gillum, M. and Shulman, G. I. (2006) Fish oil regulates adiponectin secretion by a peroxisome proliferator-activated receptor- $\gamma$-dependent mechanism in mice. Diabetes 55, 924-928

32 Haider, D. G., Mittermayer, F., Schaller, G., Artwohl, M., Baumgartner-Parzer, S. M., Prager, G., Roden, M. and Wolzt, M. (2006) Free fatty acids normalize a rosiglitazone-induced visfatin release. Am. J. Physiol. Endocrinol. Metab. 291, E885-E890

33 Hardie, D. G. (2007) AMP-activated/SNF1 protein kinases: conserved guardians of cellular energy. Nat. Rev. Mol. Cell. Biol. 8, 774-785

34 Za'tara, G., Bar-Tana, J., Kalderon, B., Suter, M., Morad, E., Samovski, D., Neumann, D. and Hertz, R. (2008) AMPK activation by long chain fatty acyl analogs. Biochem. Pharmacol. 76, 1263-1275

35 Suchankova, G., Tekle, M., Saha, A. K., Ruderman, N. B., Clarke, S. D. and Gettys, T. W. (2005) Dietary polyunsaturated fatty acids enhance hepatic AMP-activated protein kinase activity in rats. Biochem. Biophys. Res. Commun. 326, 851-858

36 Gabler, N. K., Radcliffe, J. S., Spencer, J. D., Webel, D. M. and Spurlock, M. E. (2008) Feeding long-chain $n-3$ polyunsaturated fatty acids during gestation increases intestinal glucose absorption potentially via the acute activation of AMPK. J. Nutr. Biochem. 20, 17-25

37 Fulco, M., Cen, Y., Zhao, P., Hoffman, E. P., McBurney, M. W., Sauve, A. A. and Sartorelli, V. (2008) Glucose restriction inhibits skeletal myoblast differentiation by activating SIRT1 through AMPK-mediated regulation of Nampt. Dev. Cell 14, 661-673

38 Murata, M., Kaji, H., Takahashi, Y., Iida, K., Mizuno, I., Okimura, Y., Abe, H. and Chihara, K. (2000) Stimulation by eicosapentaenoic acids of leptin mRNA expression and its secretion in mouse 3T3-L1 adipocytes in vitro. Biochem. Biophys. Res. Commun. 270, 343-348 